\title{
Pengelolaan Keuangan Keluarga di Masa Pandemi Covid-19
}

\author{
Halpiah $^{1 *}$, Hery Astika Putra ${ }^{2}$, Baiq Rizka Milania Ulfah ${ }^{3}$ \\ Universitas Islam Al-Azhar \\ 12pettamaccahaya@gmail.com, ${ }^{2}$ heryptra@gmail.com, ${ }^{3}$ rizkabaiq@gmail.com
}

\begin{abstract}
Problems that often arise in the family/ household are quite complex. One of them is economic problems or financial problems, especially during the Covid-19 pandemic requiring careful financial management by making a priority scale where prioritizing expenditures based on needs compared to spending based on desires in order to avoid debt and receivables. The method in implementing PKM is carried out in three stages, namely 1) The preparation stage includes community situation analysis, identification of problems, determining PKM work objectives, determining the theme and schedule for PKM implementation, division of PKM tasks, 2) Implementation stage including presentation of material delivery with the lecture method, question and answer session, mentoring session for making financial management to participants, 3) Evaluation stage. This PKM activity was carried out by implementing the Covid-19 Health protocol which was attended by 20 participants, which were dominated by women who were married or had families. The goal is that these housewives are able to record every income and are able to track daily expenses that have been issued in one month by way of prioritizing financial management. The conclusion from this PKM was that the 20 participants who attended had never done financial management, not because they were unable or unwilling but there had never been any socialization about financial management and the lack of basic knowledge about financial management so that economic problems in finance were always repeated. Therefore, PKM activities regarding financial management are still very important to be carried out with the main target being women / housewives as literacy efforts in financial management so that they are able to distinguish between productive expenditures and consumptive expenditures as financial managers in the family.
\end{abstract}

Keywords: Financial Management, Family, Covid-19 Pandemic

\begin{abstract}
Abstrak
Masalah yang sering muncul dalam keluarga/ rumah tangga cukup kompleks. Salah satunya adalah permasalahan ekonomi atau masalah keuangan, terutama di masa pandemi Covid-19 membutuhkan pengelolaan keuangan secara cermat dengan membuat skala prioritas dimana mendahulukan pengeluaran berdasarkan kebutuhan dibandingkan pengeluaran berdasarkan keinginan agar terhindar dari hutang piutang. Metode dalm pelaksanaan PKM ini dilaksanakan dalam tiga tahap yaitu 1) Tahap persiapan diantaranya analisis situasi masyarakat, identifikasi permasalahan, menentukan tujuan kerja PKM, penentuan tema dan jadwal pelaksanaan PKM, pembagian tugas PKM, 2) Tahap Pelaksanaan diantaranya presentasi penyampaian materi dengan metode ceramah, sesi tanya jawab, sesi pendampingan pembuatan pengelolaan keuangan pada peserta, 3) Tahap evaluasi. Kegiatan PKM ini dilaksanakan dengan menerapkan protokol kesehatan covid-19 yang dihadiri 20 peserta yang didominasi oleh perempuan yang sudah berumah tangga atau memiliki keluarga. Tujuannya adalah para ibu rumah tangga ini mampu mencatat setiap pemasukan dan mampu melakukan penelusuran pengeluaran harian yang telah dikeluarkan dalam satu bulan dengan cara pengelolaan keuangan secara prioritas. Kesimpulan yang dihasilkan dalam PKM ini adalah 20 peserta yang hadir belum pernah melakukan pengelolaan keuangan, bukan karena tidak mampu atau tidak mau tetapi belum pernah ada sosialisasi tentang pengelolaan keuangan dan minimnya pengetahuan dasar tentang pengelola keuangan sehingga permasalahan ekonomi dalam keuangan selalu berulang. Maka dari itu, kegiatan PKM tentang pengelolaan keuangan masaih sangat penting dilaksanakan dengan target utama kaum perempuan/ ibu rumah tangga sebagai upaya literasi dalam pengelolaan keuangan agar mampu membedakan antara pengeluaran produktif dan pengeluaran konsumtif selaku manajer keuangan dalam keluarga
\end{abstract}

Kata Kunci : Pengelolaan Keuangan, Keluarga, Pandemi Covid-19

*Penulis Korespondensi : Halpiah 


\section{PENDAHULUAN}

Masalah yang sering muncul dalam sebuah rumah tangga cukup kompleks salah satunya yang selalu menjadi momok adalah permasalahan ekonomi yaitu masalah keuangan yang serimg dikaitkan dengan utang piutang, kekurangan daya beli, penghasilan yang minim tidak berimbang dengan pengeluaran yang lebih besar sesuai dengan pepatah lebih besar pasak daripada tiang, permasalahan ini lumrah terjadi pada keluarga atau rumah tangga dari kalangan menengah ke bawah hidup dari hasil gali lubang tutup lubang dimana kebutuhan terpenuhi dari hasil utang sehingga penghasilan yang di peroleh selalu tidak cukup untuk memenuhi konsumsi belanja dapur, biaya pendidikan anak, membayar kredit motor, perabot, peralatan rumah tangga dan lain-lain seperti yang sering di ucapkan ibu rumah tangga tidak kredit tidak bisa memiliki asset, namun jargon ini tidak diimbangi kemauan para anggota kelurga menyeimbangkan antara penghasilan dan pengeluaran dengan melakukan pengelolaan keuangan yang terencana sejak awal membina rumah tangga antara pasangan suami istri. Disini, pengelolaan keuangan harus memiliki perencanaan keuangan untuk mencapai tujuan jangka pendek maupun jangka panjang. Untuk mencapai tujuan tersebut, maka perlu ada pengalokasi dana yang baik sehingga tidak terjebak pada perilaku keinginan yang tak terbatas (Silvy and Yulianti, 2013)

Setiap individu dalam rumah tangga baik sudah menikah maupun belum pasti pernah merasakan dan menghadapi permasalaan keuangan, hal lumrah yang sering terucap adalah saya kekurangan uang padahal realitanya bukan kekurangan uang namun beban lebih tinggi daripada pendapatan sehingga setiap individu dan keluarga selalu merasa kekurangan uang di karenakan dalam pengeluaran atau konsumi belum menerapkan skala perioritas yang membedakan antara kebutuhan dan keinginan. Hal ini bisa terjadi ketika keluarga tidak memiliki pengetahuan akuntansi atau tidak memahami manajemen keuangan dalam keluarga. Kurang memadainya pengetahuan tentang merencanakan dan mengatur kuangan menyebabkan tujuan untuk mencapai kesejahteraan tidak tercapai (Mulyati and Hati, 2021)
Pengelolaan keuangan adalah teknik mengimbangi gaya hidup manusia seperti gaya hidup konsumtif dengan gaya hidup produktif seperti investasi, menabung maupun bisnis (Senduk, 2004). Adapun tujuan pengelolaan keuangan agar kita terhindar dari kondisi lebih banyak hutang daripada pemasukan. Sedangkan menurut Wardana et al., (2017) menjelaskan bahwa pengeluaran konsumsi merupakan belanja yang di lakukan oleh rumah tangga merupakan bagian dari pendapatan rumah tangga yang di belanjakan untuk makan dan non makanan. Tingkat pengetahuan keuangan adalah hal yang paling penting karena memungkinkan individu untuk memahami mengelola keungan keluarga serta memiliki perilaku penghematan, (lasuardi, 2008). Pengetahuan tentang keuangan menjadi sangat penting bagi individu agar tidak salah dalam membuat keputusan keuangan nantinya (Margaretha and Pambudhi, 2015).

Pengelolaan keuangan pribadi dapat dilihat dari empat ranah (Warsono, 2011) :

1. Penggunaan dana. Darimanapun sumber dana yang dimiliki yang menjadi persoalan adalah bagaimana cara mengalokasikannya untuk memenuhi kebutuhan secara tepat berdasarkan skala perioritas seperti mengalokasikan dana $70 \%$ untuk pemenuhan konsumsi sehari-hari, 20\% untuk di tabung dan $10 \%$ untuk investasi.

2. Penentuan sumber Dana. Seseorang harus mengetahui dan menentukan sumber dananya dari mana berasal agar mampu mencari sumber dana alternative lain sebagai sumber pemasukan keuangan untuk di kelola.

3. Manajemen Resiko. Seseorang haruslajh memiliki proteksi yang baik untuk mengantisipasi kejadian-kejadian tidak terduga.

4. Perencanaan Masa Depan. Dengan merencanakan masa depan maka anda juga menganalisa kebutuhan dimasa depan sehingga anda menyiapkan investasi dari saat ini.

Cara cermat pengelolaan keuangan keluarga setiap keluarga wajib mencermati setiap pengeluarannya agar tingkat konsumtif tidak lebih 
besar dari pendapatan. Hal tersebut bisa di lakukan dengan cara sebagai berikut :

1. Buat perencanaan keuangan sedini mungkin untuk menghindari resiko infalsi di masa depan dengan mengalih kan sebagian pendpatan ke investasi.

2. Buatlah daftar pendapatan yang rinci agar disesuaikan dengan pengeluaran anda sehingga tidak menimbulkan hutang berlebihan yang membani tabungan anda.

3. Buatlah sekala perioritas dengan membedakan pengeluaran produktif dan pengeluaran konsumtif.

4. Selalu melakukan perhitungan di setiap pengeluaran dengan cara memangkas pengeluaran yang tidak penting.

5. Jaga dana tabungan semaksimal mungkin minimal $10 \%$ dari pendapatan dan selalu katakan saya tidak memiliki uang yang cukup jika godaan konsumtif yang tidak berfaedah meningkat.

6. Komunikasikan dengan keluarga tentang batas penggunaan anggaran belanja bulanan agar semua keuarga memahami apa yang harus dilakukan agar berhemat dan mengutakamakan menabung atau berinvestasi.

Dalam situasi kondisi normal suatu pengelolaan keuangan yang salah bisa menimbulkan banyak masalah bagi keluarga, apalagi dalam situasi pendemi covid-19 seperti saat ini, dimana mungkin ada salah satu anggota keluarga yang terdampak seperti pemutusan hubungan kerja sehingga menyebabkan berkurangnya penghasilan namun pengeluaran atau konsumsi sama atau meningkat tentunya ini bisa menjadi permasalahan besar jika keluarga tidak melakukan penghematan dan melakukan pengelolaan keuangan. Berdasarkan permasalahan tersebut kami berinisiatif melaksanakan kegiatan pengabdian kepada masyarakat dengan tema" Pentingnya Pengelolaan Keuangan Dalam Keluarga Di Masa Pandemic Covid19”. Yang telah di laksanakan pada bulan april $2021 \mathrm{di}$ lingkungan turida barat kelurahan turida.

Berdasarkan uraian pendahuluan dan latar belakang yang telah di jelaskan sebelumnya. maka rumusan masalah dalam kegiatan PKM ini adalah :
1. Bagaimana pengelolaan keuangan yang tepat bagi keluarga di masa pandemic covid-19.?

2. Bagaimana cara meminimalisir pengeluaran konsumtif dalam keluarga agar bisa berhemat di masa pandemi covid-19?

Sedangkan tujuan dari pelaksanaan kegiatan Pengabdian Kepada Masyarakat ini adalah sebagai berikut :

1. Untuk mengetahui pengelolaan keuangan yang tepat bagi keluarga di masa pandemi COVID-19.

2. Untuk mengetahu cara meminimalisir pengeluaran konsumtif dalam keluarga di masa pandemic COVID-19.

Sehingga manfaat yang bisa di petik dalam kegiatan pengabdian kepada masyarakat ini adalah :

1. Para keluarga yang hadir dapat menambah pengetahuan dan pemahaman tentang pengelolaan keuangan dalam keluarga berdasarkan manajemen keuangan dan akuntansi.

2. Para keluarga mampu membuat skala prioritas dalam setiap pengeluaran yang mereka rencanakan agar terhindar dari sifat konsumtif.

\section{METODE}

Metode pelaksanan dalam kegiatan pengabdian kepada masyarakat dengan judul pengelolaan Keuangan keluarga di masa Pandemi COVID-19 dilaksanakan dalam tiga tahap yaitu :

1. Tahap Persiapan diantaranya :

a. Analisis Situasi Masyarakat. Metode ini dilakukan dengan cara melakukan observasi lapangan agar kita bisa mengetahui permasalahan yang di hadapi oleh masyarakat yang akan menjadi tarket dalam kegiatan PKM,

b. Identifikasi permasalahan yang dihadapi oleh masyarkat dari hasil observasi dan wawancara dengan kepala lingkungan beserta beberapa perwakilan masyarakat dalam hal ini masyarakat yang sudah berumah tangga dan memiliki keluarga mereka mengemukakan permasalan pelik yang dihadapi di masa pandemic covid-19 adalah kesusahan dalam mengelola keuangan agar mampu memenuhi kebutuhan sehari-hari di karenakan pendapatan berkurang akibat 
penerapan social distancing oleh pemerintah agar mengurangi penyebaran virus covid-19. Berdasarkan hal ini tim PKM sepakat mengadakan sosialisasi pengelolaan keuangan dalam keluarga karna permasalahan ini mendesak dilaksanakan agar masyarakat keluarga mampu bertahan di masa pandemic covid-19 dengan cara melakukan pengelollaan keuangan yang tepat sasaran.

c. Menentukan Tujuan Kerja PKM tujuan dari pelaksanaan PKM tersebut adalah mengedukasi individu yang sudah berumah tangga keluarga agar melakukan pengelollaan keuangan yang tepat agar pendapatan atau pengasilan minimal yang mereka dapatkan di alokasikan sesuai kebutuhan dengan mengesampingkan keingunan agar mampu berhemat dan meminimalisisr pengeluaran yang tidak bermamfaat dan tentunya tidak menambah hutang yang membebani keuangan keluarga..

d. Penentuan tema dan jadwal pelaksaan PKM. dalam hal penentuan tema dan jadwal pelaksanaan PKM di lksanakan atas dasar kesepakatan antara kepala lingkungan, imam masjid dan perwakilan tokoh masyarakat. Tentunya juga atas pengetahuan LPPM universitas yang menaungi TIM PKM.

e. Pembagian Tugas Tim PKM

2. Tahap Pelaksanaan kegiatan PKM.

a. Presentasi penyampaian materi dengan metode ceramah untuk memberikan penegetahuan dan pemahaman tentang pentingnya pengelolaan keuangan di masa pandemic COVID-19 yang meliputi: pemaparan materi tentang pengertian pengelolaan keuangan, dan memberikan contoh pencatatan sederhana tentang pengeluaran harian yg sesuai skala prioritas.

b. Setelah pemaparan materi di lanjutkan dengan sesi tanya jawab antara tim dan peserta PKM, metode ini sangat penting untuk memberikan ruang pada warga yang hadir untuk bertanya tentang pengelolaan keuangan yang mereka tidak ketahui selama ini. c. Selanjutnya di berikan pendampingan pembuatan pencatatan keuangan sederhana tentang pengeluaran harian yang bisa di terapkan oleh warga masyarakat didampingi oleh mahasiswa program studi akuntansi. Sejumlah lima mahasiswa.

3. Tahap evaluasi

Evaluasi kegiatan diikuti oleh seluruh peserta untuk mengecek hasil pencatatan pengeluaran berdasarkan skala prioritas yaitu membedakan pengeluaran produktif dan pengeluaran konsumtif sesuai dengan materi yang telah dijabarkan saat presentasi dan pendampingan pembuatan pencatatan pengelolaan keuangan keluarga

\section{HASIL DAN PEMBAHASAN}

Hasil Kegiatan Pengabdian Kepada Masyarakat berupa sossialisasi pentingnya pentingnya pengelolaan keuangan dalam keluarga di masa pandemic Covid-19 yang telah di laksanakan pada bulan april tahun 2021 di teras masjid Mambaul Hasanah linkungan Turida barat kelurahan turida kecamatan. Sandubaya kota mataram NTB. Berjalan sesuai harapan di hadiri warga masyarakat yang di dominasi oleh perempuan atau ibuibu rumah tangga kepala lingkungan, imam masjid dan perwakilan dari kelurahan dimana peserta di batasai hanya maksimal 25 peserta sesuai anjuran pemerintah dengan menerapkan protokol kesehatan. Kegiatam PKM di laksanakan oleh tiga orang dosen dengan melibatkan lima orang mahasiswa dari Program Studi Akuntansi, Fakultas Ekonomi, Universitas Islam AlAzhar

Kegiatan disambut hangat oleh peserta PKM dengan tertib mengikuti tiga sesi acara yaitu sesi pertama pembukaan dan kata sambutan oleh kepala lingkungan dan imam masjid Turida Barat, dilanjutkan dengan pengenalan dan penyampaian maksud dan tujuan kegiatan oleh Tim PKM dan diteruskan dengan penyampain materi sosialisasi dengan menjabarkan pengertian pengelolaan keuangan dan pentingnya diterpkan dalam keluarga agar mampu bertahan tanpa menambah hutang di tengah masa pandemi COVID-19 yang masih mewabah sampai saat ini materi tersebut di sampaikan oleh ibu Halpiah, SE.,M.Ak melalui metode 
ceramah dengan interaksi dengan peserta yang sesekali diselingi humor khas ibu-ibu agar kegiatan tidak terasa membosankan, setelah pemaran materi kegiatan di lanjutkan dengan sesi tanya jawab dimana pemateri memberikan waktu pada peserta untuk bertanya dan memberikan pernyataan tentang pengelolaan keuangan. Dalam sesi ini, tak di sangka semua peserta sangat antusias angkat tanngan berlomba ingin menyampaikan pertanyaan karena bagi mereka materinya menarik dan dialami lansung oleh peserta terutama perempuan atau ibu rumah tangga yang notabenenya sebagai manajer keuangan dalam keluarga. Bagi mereka sosialisasi ini sangat bermanfaat setidaknya membantu mereka mengetahui bahwa uang pendapatan pribadi dan pasangan atau suami/istri ternyata harus dikelola agar pengeluaran konsumtif yang tidak penting bisa di minimalisir.

Ditengah sesi hanya jawab imam masjid sempat meminta waktu untuk memberikan pernyataan beliau menyatakan makanya ibu-ibu jadilah perempuan cerdas dengan menambah ilmu melalui kegiatan seperti ini jangan malas untuk terus belajar karena menghadiri kegiatan bermanfaat seperti ini mendapatkan tiga faedah yaitu pengetahuan, silaturahim memperpanjang usia dan membuka pintu rezeki. Setelah sesi taya jawab agar materi lebih dipahami oleh peserta kami Tim PKM melanjutkan dengan memberikan contoh sekaligus pendampingan penbuatan pencatatan sederhana berupa pencatatan jumlah pemasukan dan pengeluaran dalam satu bulan agar para kelurga ini mampu menelusuri biaya yang telah di kelurkan selama satu bulan berjalan, sehingga mereka bisa melakukan disiplin melakukan penghemtan serta mengalokasikan penghasilan/pendapatan minimal $10 \%$ dalam bentuk tabungan.

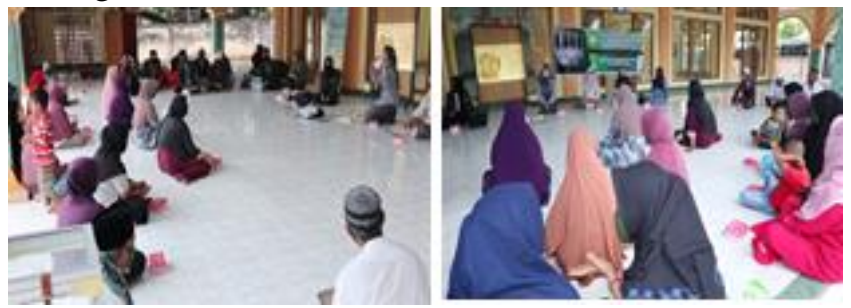

Gambar 1. Presentasi materi dalam kegiatan PKM
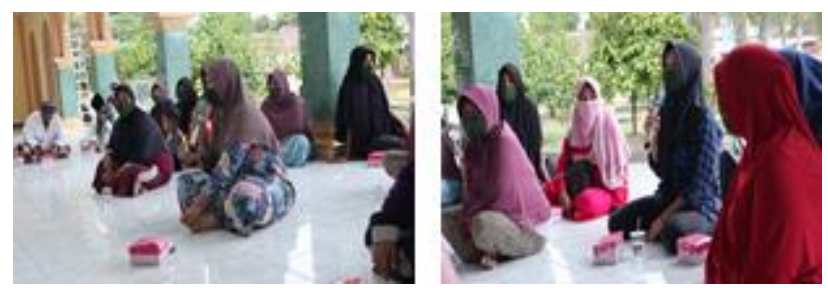

Gambar 2. Sesi Tanya Jawab

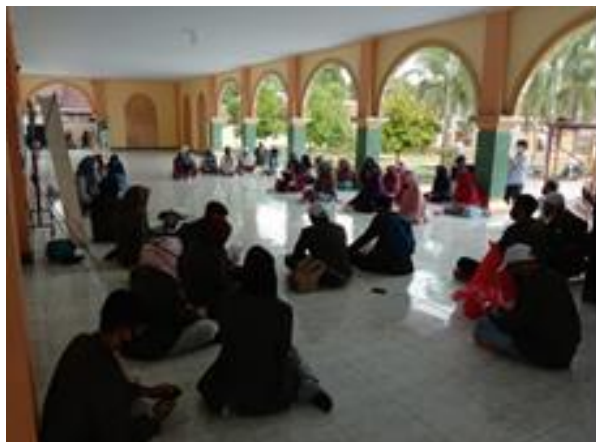

Gambar 3. Pendampingan Pencatatan Pengelolaan Keuangan Rumah Tangga

Keberhasilan kegitan PKM dapat dilihat dari antusias peserta untuk hadir namun kondisi peserta dibatasi kehadirannya. Selanjutnya, dari bapak kepala lingkungan menyampaikan harapannya agar kegiatan seperti ini diadakan secara berkala dengan berbeda peserta agar minimal $50 \%$ perempuan dan ibu rumah tangga yang ada di Lingkungan Turida Barat paham tentang pengelolaan keuangan, karena itu modal utama dalam menjalankan roda kehidupan dalam berumah tangga.

Berikut adalah contoh pengelolaan keuangan rumah tangga :

Tabel 1. Contoh Pengelolaan Keuangan Rumah Tangga

\begin{tabular}{|c|c|c|c|c|}
\hline \multirow{2}{*}{ NO } & & & & \\
\hline & \multicolumn{2}{|c|}{ ITEM } & \multicolumn{2}{|c|}{ JUMLAH (Rp) } \\
\hline \multirow[t]{4}{*}{1} & \multicolumn{2}{|c|}{ Pemasukan (Bulanan): } & & \\
\hline & \multicolumn{2}{|c|}{ - Gaji (Bulanan) } & \multirow{2}{*}{\multicolumn{2}{|c|}{$\begin{array}{l}2.000 .000 \\
1.000 .000\end{array}$}} \\
\hline & \multicolumn{2}{|c|}{$\begin{array}{l}\text { - Pendapatan } \\
\text { Lainnya }\end{array}$} & & \\
\hline & $\begin{array}{l}\text { Total } \\
\text { bulanan }\end{array}$ & (Pemasukan) & & 3.000 .000 \\
\hline 2 & $\begin{array}{l}\text { Pengelu } \\
\text { aran } \\
\text { rutin } \\
\text { (bulanan } \\
\text { ): }\end{array}$ & & & \\
\hline & Hutang & $\begin{array}{l}\text { Cicilan /sewa } \\
\text { rumah }\end{array}$ & 500.000 & \\
\hline
\end{tabular}




\begin{tabular}{|c|c|c|c|c|}
\hline \multirow[t]{2}{*}{ NO } & \multicolumn{2}{|c|}{ ITEM } & \multicolumn{2}{|c|}{ JUMLAH (Rp) } \\
\hline & & $\begin{array}{l}\text { Cicilan } \\
\text { Kendaraan }\end{array}$ & 600.000 & \\
\hline & Zakat & Zakat & 75.000 & \\
\hline & $\begin{array}{l}\text { Investas } \\
\mathrm{i}\end{array}$ & Tabungan & 100.000 & \\
\hline & $\begin{array}{l}\text { Biaya } \\
\text { Rutin(B } \\
\text { ulanan) }\end{array}$ & Pendidikan & 200.000 & \\
\hline & & Kesehatan & 150.000 & \\
\hline & & Biaya Listrik & 100.000 & \\
\hline & & Biaya Air & 45.000 & \\
\hline & & Biaya Pulsa & 50.000 & \\
\hline & & $\begin{array}{l}\text { Biaya } \\
\text { Transportasi }\end{array}$ & 150.000 & \\
\hline & & $\begin{array}{ll}\text { Uang } & \text { Saku } \\
\text { Harian } & \\
\end{array}$ & 280.000 & \\
\hline & & $\begin{array}{l}\text { Belanja } \\
\text { Rumah } \\
\text { Tangga (lauk } \\
\text { pauk) }\end{array}$ & 600.000 & \\
\hline & & $\begin{array}{ll}\text { Biaya } & \text { Tak } \\
\text { Terduga } & \\
\end{array}$ & 100.000 & \\
\hline & Hiburan & Rekreasi & 50.000 & \\
\hline & $\begin{array}{l}\text { Total } \\
\text { (Pengel } \\
\text { uaran) } \\
\text { Bulana } \\
\text { n }\end{array}$ & & & 3.000 .000 \\
\hline
\end{tabular}

\section{KESIMPULAN}

Setelah kegiatan pengabdian kepada masyarakat ini terlaksana dapat ditarik kesimpulan bahwa masih banyak perempuan atau ibu rumah tangga dan kelurga yang tidak memiliki pengetahuan dasar tentang pengelolaan keuangan sehingga permasalahan ekonomi dalam keluarga selalu berulang bahkan menjadi pemicu utama komplik dalam keluarga. Maka dari itu kegiatan PKM dengan mengangkat tema pengelplaan keuangan masih sangat penting untuk diadakan dengan target utama kaum perempuan atau ibu rumah tangga agar mereka mendapatkan literasi tentang pengelolaan keuangan dan mampu mengelola keuangan dalam rumah tangga, melakukan pencatatan pengeluaran dengan menerapkan skala perioritas dengan membedakan pengeluaran produktif dan pengeluaran konsumtif serta memetakan antara kebutuhan dan keinginan.

\section{UCAPAN TERIMA KASIH}

Kami selaku Tim Pelaksana mengucapkan terima kasih kepada Bapak Lurah Kelurahan Turida, Kepala Lingkungan Turida Barat, Imam Masjid Mamba'ul Husna Turida Barat, warga masyarakat di Lingkungan Turida Barat dan Universitas Islam Al-Azhar yang telah mendukung terlaksananya kegiatan pengabdian masyarakat serta para mahasiswa yang terlibat sehingga acara dapat berjalan dengan lancar sesuai dengan protokol kesehatan pencegahan COVID-19.

\section{DAFTAR PUSTAKA}

Margaretha, F. and Pambudhi, R. A. (2015) 'Tingkat literasi keuangan pada mahasiswa S-1 fakultas ekonomi', Jurnal Manajemen dan Kewirausahaan, 17(1), pp. 76-85.

Mulyati, S. and Hati, R. P. (2021) 'Pengaruh Literasi Keuangan Dan Sikap Terhadap Uang Pada Pengelolaan Keuangan Keluarga', Jurnal Ilmiah Akuntansi dan Finansial Indonesia, 4(2), pp. 33-48.

Senduk, S. (2004) 'Siapa Bilang Jadi Karyawan Nggak Bisa Kaya: Lima Kiat Praktis Mengelola Gaji Agar Bisa Kaya', Jakarta: Elex media komputindo.

Silvy, M. and Yulianti, N. (2013) 'Sikap pengelola keuangan dan perilaku perencanaan investasi keluarga di Surabaya', Journal of Business and Banking, 3(1), pp. $57-68$.

Wardana, A. et al. (2017) Analisis Ekonomi Jawa Barat. UNPAD PRESS

Warsono, W. (2011) 'Prinsip-Prinsip dan Praktik keuangan Pribadi', Jurnal Salam, 13(2). 